University of Michigan Law School

University of Michigan Law School Scholarship Repository

\title{
The Hidden Disability Consensus in the 2020 Campaign
}

\author{
Harold A. Pollack \\ University of Chicago School of Social Service Administration \\ Samuel R. Bagenstos \\ University of Michigan Law School, sambagen@umich.edu
}

Available at: https://repository.law.umich.edu/articles/2338

Follow this and additional works at: https://repository.law.umich.edu/articles

Part of the Disability Law Commons, and the Health Law and Policy Commons

\section{Recommended Citation}

Pollack, Harold A. and Samuel R. Bagenstos. "The Hidden Disability Consensus in the 2020 Campaign."

JAMA Health Forum 1, no. 2 (2020). doi:10.1001/jamahealthforum.2020.0152

This Article is brought to you for free and open access by the Faculty Scholarship at University of Michigan Law School Scholarship Repository. It has been accepted for inclusion in Articles by an authorized administrator of University of Michigan Law School Scholarship Repository. For more information, please contact mlaw.repository@umich.edu. 


\section{JAMA Health Forum.}

\section{Insights | Election 2020 \\ The Hidden Disability Consensus in the 2020 Campaign}

Harold A. Pollack, MPP, PhD; Samuel R. Bagenstos, BA, JD

At this writing, the final results of the lowa caucuses remain unreported. No one yet knows which candidates did well and which did poorly. We do know that health policy is a defining cleavage between left and liberal Democrats this primary season. Much of the press coverage will naturally focus on the implications of this vote for Democrats' commitment to an incremental public option or a full-throated single-payer plan.

Another matter will receive less coverage but may be equally significant for health policy should the Democratic nominee prevail in November: the emerging consensus among Democrats (and potentially among many Republicans, too) regarding disability and long-term care. Quietly but with purpose, several candidates present a humane and ambitious agenda to address key defects in our current tapestry of supports for Americans who live with disabilities or chronic illness.

Three of the leading Democratic contenders-Senator Warren, Senator Sanders, and Mayor Buttigieg-present particularly detailed and actionable plans. Some of what they propose will only be possible with the (unlikely) passage of their ambitious and comprehensive health care plans. Whatever the fate of their overall proposals, many of their specific disability provisions could be readily translated into discrete pieces of legislation should a Democrat win the presidency. Some of what they propose might be legislated right now, with at least some possibility of bipartisan support.

A short commentary cannot engage the full complexity of these proposals. Some components to address social determinants bear brief mention. Most Democratic candidates endorse full or greatly expanded funding for the Individuals with Disabilities Education Act (IDEA) to address educational barriers faced by students who live with disabilities. The underfunding of IDEA has been a persistent problem for Americans with disabilities, and one is entitled to be skeptical that-finally, this time-the candidates will truly follow through on their promise of full funding. But the broad consensus on the issue in the Democratic primary suggests that the proposal now has its strongest chance in recent history of being enacted.

The Democratic candidates propose to ensure that services for students with disabilities don't end with high school. They support changes to the often-punitive work disincentives in Supplemental Security Income (SSI) and Social Security Disability Insurance (SSDI). Most of the candidates support improved wages and work conditions for direct care workers who provide essential services to individuals with disabilities. Some would relax the age constraints that now govern Achieving a Better Life Experience accounts-a savings opportunity effectively shielded from SSI asset limits but now open only to Americans who develop a disability before age 26 . And virtually all of them support expansion of community-based services and supports to enable people with disabilities to live full lives in their own homes and neighborhoods. Virtually all support measures to ameliorate the criminalization of mental illness.

Two examples within the traditional domain of health coverage illustrate the emerging Democratic consensus.

- Candidates Warren, Sanders, and Buttigieg would eliminate the 24-month waiting period before most SSDI recipients can access Medicare. All the way back in 2008, Senator Max Baucus included such a proposal in his famous white paper that in many ways prefigured the Patient Protection and Affordable Care Act (ACA). ${ }^{1}$ This proposal somehow fell by the wayside in the various negotiations that led to health care reform.
Author affiliations and article information are listed at the end of this article. 
- Candidates also propose to eliminate or substantially increase the countable asset limit for SSI recipients with disabilities who rely on Medicaid. These countable asset limits are astonishingly low: $\$ 2000$ for an individual and $\$ 3000$ for couples. Adjusting for inflation, these thresholds are less than one-quarter of what they were in 1972. They have not increased since 1989, more than 30 years ago.

The detail and ambition of the candidates' proposals are striking. Equally striking is their pragmatism and apparent political and legislative feasibility. Some of the proposals are costly, but they would not require the creation of massive and complex new programs.

Such measures could be enacted without requiring a legislative supermajority. They would not fundamentally disrupt the structure of American health care. This fact marks a fundamental difference from the broader health policy debate about Medicare for All and other proposals of far greater complexity-proposals that have little immediate prospect of becoming law.

Democrats' 2020 proposals also mark a departure from the curiously marginalized role of disability policy and disability constituencies within prior health reform efforts. ${ }^{2}$ In retrospect, the ACA must be regarded as a substantial missed opportunity to address many gaps in our current disability system. Democrats don't want to make the same mistakes again.

Many Democrats' positions appear to have been crafted in response to questions raised by leaders within the disability community itself-particularly the influential questions raised by the Center for American Progress's Rebecca Cokley. ${ }^{3}$

Although these proposals are generated in the context of a primary fight, many have some prospect of bipartisan support, given 2 realities. Illness and disability cross every partisan, economic, geographic, and cultural line. As Republicans learned to their sorrow in the ill-fated effort to repeal the ACA, Americans with disabilities, their allies, and their caregivers are a potent constituency.

Bipartisan legislation has already been proposed to eliminate SSDI's Medicare waiting period. ${ }^{4}$ House bill HR 4280 and Senate bill S 2753 (Senators Warren and Sanders, cosponsors) would raise asset limits to $\$ 10000$ for individuals and $\$ 20000$ for couples. ${ }^{5,6}$

It's too soon to tell what lowa's results portend this political season. It's not too soon to discern that disability policy will be an important battleground in the 2020 campaign. A Democratic victory could herald major changes that would affect the lives of millions of Americans with disabilities, their loved ones, and others close to them.

Policy reform requires a difficult balance of aspiration, political realism, and pragmatic urgency in tackling urgent social problems. The front-runners in lowa are still seeking this balance along the trajectory to universal coverage. They are finding their footing in the arena of disability policy. This is one of the great undercovered stories this campaign year.

\section{ARTICLE INFORMATION}

Open Access: This is an open access article distributed under the terms of the CC-BY License.

Corresponding Author: Harold A. Pollack, MPP, PhD, University of Chicago School of Social Service Administration, 969 East 60th Street, Chicago, IL 60637 (haroldp@uchicago.edu).

Author Affiliations: University of Chicago School of Social Service Administration, Chicago, Illinois (Pollack); University of Michigan Law School, Ann Arbor, Michigan (Bagenstos).

Conflict of Interest Disclosures: None reported.

Acknowledgment: Thanks to Tonie Sadler for useful comments.

\section{REFERENCES}

1. Baucus M. Call to Action: Health Reform 2009. Washington, DC: Senate Finance Committee. Published November 12, 2008. Accessed February 5, 2020. https://www.finance.senate.gov/imo/media/doc/ finalwhitepaper1.pdf

2. Pollack H. Health-care reform's disability blind spot. The American Prospect. Published January 9, 2018. Accessed February 5, 2020. https://prospect.org/health/health-care-reform-s-disability-blind-spot/ 
JAMA Health Forum | Insights

3. Cokley R. 10 disability policy questions every presidential candidate should answer. Center for American Progress. Published October 15, 2019. Accessed February 5, 2020. https://www.americanprogress.org/issues/ disability/news/2019/10/15/475859/10-disability-policy-questions-every-presidential-candidate-answer/

4. Bill would eliminate Medicare waiting period for people with disabilities. The Commonwealth Fund. Published June 13, 2005. Accessed February 5, 2020. https://www.commonwealthfund.org/publications/newsletter-article/ bill-would-eliminate-medicare-waiting-period-people-disabilities

5. Supplemental Security Income Restoration Act of 2019, HR 4280, 116th Cong (2019-2020).

6. Supplemental Security Income Restoration Act of 2019, S 2753, 116th Cong (2019-2020). 